\title{
34. PALEOGENE AND NEOGENE SPONGE SPICULES FROM SITES 511, 512, AND 513 IN THE SOUTH ATLANTIC 1
}

Mikhail M. Ivanik, Institute of Geological Sciences, Academy of Sciences of the Ukrainian S.S.R., Kiev, U.S.S.R.

\begin{abstract}
Sponge spicules found in Eocene, Oligocene, and middle Miocene sediments at DSDP Leg 71 Sites 511, 512, and 513 belong to two classes; Hyalospongiae and Demospongiae. On the basis of spicule types and stratigraphic characteristics, spicule assemblages are distinguished for the lower and upper units of the middle Eocene, the upper Eocene, the lower Oligocene, the lower and upper units of the upper Oligocene, and the middle Miocene. In addition, 23 types and 76 dimensional varieties of spicules are described.
\end{abstract}

\section{INTRODUCTION}

Abundant sponge spicules in Eocene, Oligocene, and Miocene sediments from DSDP Leg 71 sites formed the basis for an investigation of the composition and range of sponge remains, in order to clarify their potential use in stratigraphic subdivision and in interpretation of the depositional conditions of Paleogene and Neogene sediments in the South Atlantic.

Sponge spicules encountered in washed fractions of Cenozoic sediment from Leg 71 fall into two classes, Hyalospongiae and Demospongiae. The classification of sponge spicules into lower taxonomic units is difficult, calls for special explanation, and is considered later in this chapter. At the Leg 71 sites, moreover, there were found some peculiar spicules that were similar to spicules identified by Lendenfeld (1915) as "the outer protruding rays." These unfortunately were only fragments, so that it is difficult to resolve unambiguously their systematic affinity. Haeckel and Giltsch (Haeckel, 1887) described similar rays and classified them as radiolarians of the family Orosphaeridae. Here I have noted their variation and characteristic stratigraphic range, but have not described them in detail. In general, dissimilar vertical ranges of isolated sponge spicules are used to define discrete spicules or spicule varieties characteristic of particular stratigraphic units.

\section{SPONGE SPICULE DISTRIBUTION}

\section{Site 511}

Site 511 was drilled at the eastern end of the Falkland Plateau (Maurice Ewing Bank), at $51^{\circ} 00.28^{\prime} \mathrm{S} ; 46^{\circ}$ $58.30^{\prime} \mathrm{W}$, in a water depth of 2589 meters (Fig. 1).

Sponge spicules were found in muddy diatomaceous ooze and muddy nannofossil diatomaceous oozes of upper Eocene and lower Oligocene deposits (thickness, $163.5 \mathrm{~m}$ ). These oozes rest unconformably on upper $\mathrm{Pa}-$ leocene-lower Eocene pelagic clay and are disconformably overlain by upper Pliocene sediments.

\footnotetext{
${ }^{1}$ Ludwig, W. J., Krasheninnikov, V. A., et al., Init. Repts. DSDP, 71: Washington (U.S. Govt. Printing Office).
}

In the upper Eocene and lower Oligocene sediments of Hole 511, spicules of the order Hexactinellida were found. They include hexactines, pinules, oxyhexactines, pentactines, anapentactines, stauractines, and dictyine skeleton fragments (Fig. 2). In the lower half of the lower Oligocene microscleres of the order Amphidiscophora are present (amphidiscs are typical). The order Tetraxonida was represented by orthodichotriaenes, plagiodichotriaenes, anadichodiaenes, anatriaenes, and plagiotriaenes. Upward in the section the quantity and diversity of Tetraxonida spicules diminishes (Fig. 2). Monaxon spicules were represented by styles, subtylostyles, oxeas, and strongyles.

The most characteristic spicules of the upper Eocene deposits are sigmas and anaorthotriaenes (dimensional variety [DV] DV 7a). Common also are bow-shaped oxeas (DV 2) and crooked oxeas (DV 2). Plagiotriaenes (DV 4), anadichodiaenes, bow-shaped styles (DV 6), rough-headed subtylostyles (DV 4), and oxeas transitional to styles were present, although rare.

The varieties of spicules found in the upper Eocene and the lower part of the lower Oligocene sediments include bow-shaped oxeas (DV 3), subtylostyles (DV 5), prodichotriaenes, orthodichotriaenes (DV 2), and oxyhexactines (DV 6).

The most characteristic and frequent sponge spicule types and varieties in the lower Oligocene are proanatriaenes (DV 1), thorned oxyhexactines (DV 2), dictyine skeleton fragments, hexactines with underdeveloped branches (DV 4), and hexactines (DV 3). Oxyhexactines (DV 7), amphidiscs, bow-shaped styles (DV 5), bowshaped oxeas (DV 6), and plagiomesotriaenes were present, although rare.

One group of spicule varieties that is characteristic of the lowermost Oligocene (Sample 511-12,CC to Sample $511-17, C C)$ consists of plagiodichotriaenes (DV 1, DV 2 , DV 3, and DV 4), proanatriaenes (DV 2), and orthotriaenes.

Among the sponge spicule varieties from the lower Oligocene and upper Eocene sections were distinctive spicules that had one sharp point at one end and generally branched at an acute angle (with broken edges) at the other end. Because no spicules with solid processes 


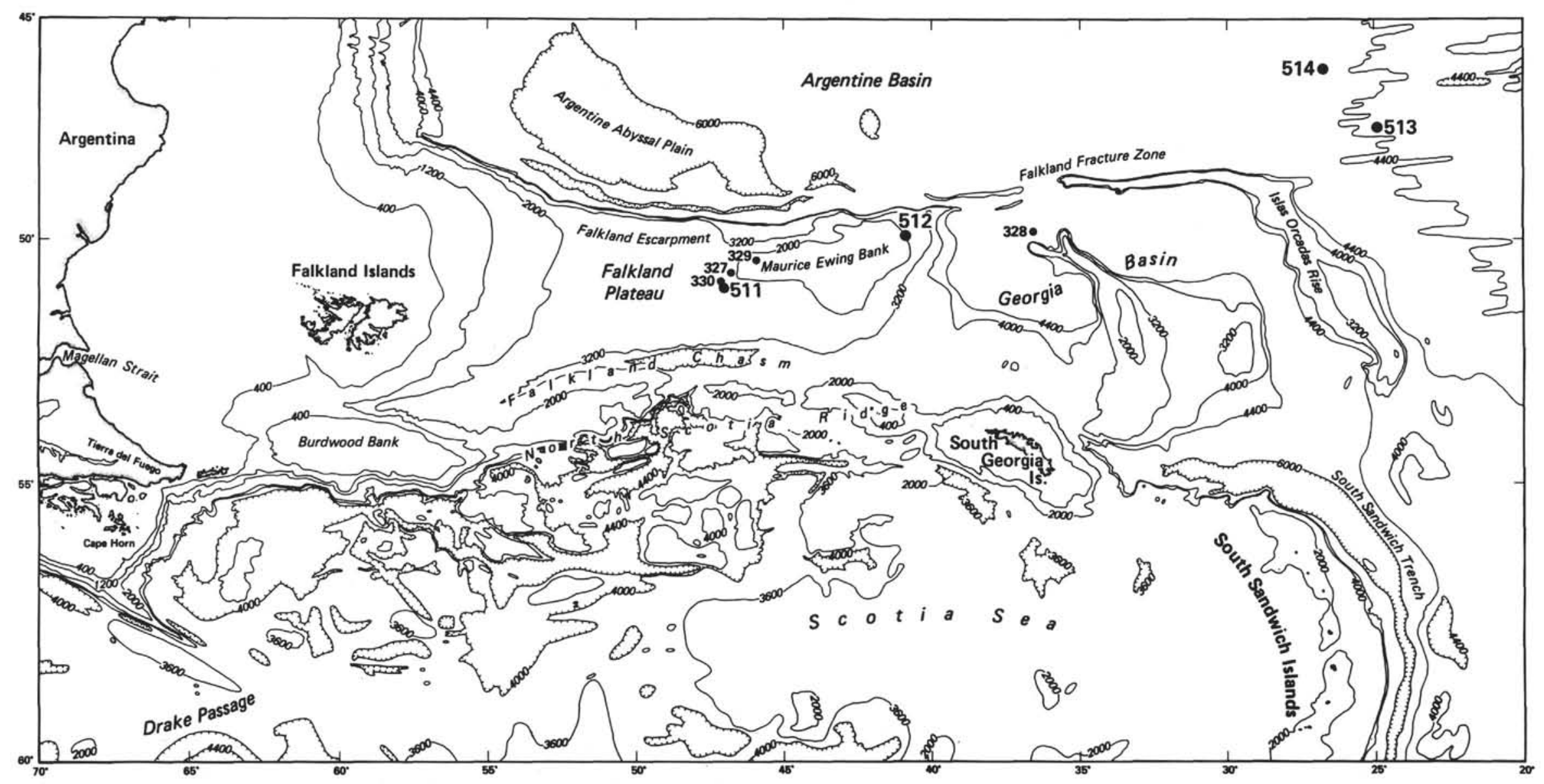

Figure 1. Location of Leg 71 sites. 
from the main ray branchings were found, the relation of these spicules to well-defined varieties is arguable. Nevertheless, judging by morphological aspects of these rays (right, hooked, rough, etc.) I have subdivided them into groups which occupy definite stratigraphic positions in a section. Prominent right massive rays, prominent right rays with rounded ends, and prominent, hooked, rough rays were found only in the lower Oligocene sediments (from Sample 511-2-3, 105-107 cm to Sample 511$16, \mathrm{CC})$. Hooked rostriform rays are abundant in the upper Eocene and lowermost Oligocene (Sample 511-16$2,30-32 \mathrm{~cm}$ to Sample 511-20,CC).

In summary, the main characteristics of sponge spicule assemblages from upper Eocene and lower Oligocene sediments are as follows:

1) Only the upper Eocene sponge spicule complexes contain sigmas - sponge microscleres of the class Demospongiae such as crooked oxeas (DV 2) and bow-shaped styles (DV 3, DV 6).

2) Only in sponge spicule assemblages from the lower Oligocene were there oxyhexactines (DV 2), fragments of dictyine skeletons of hexactinal sponges, hexactines with a pair of rudimentary branches, amphidiscs, and other rare spicule varieties.

3) There is a marked predominance of triaenes and monaxons in the upper Eocene and at the bottom of lower Oligocene.

\section{Site $\mathbf{5 1 2}$}

Site 512 was drilled on the eastern margin of the Maurice Ewing Bank, at $49^{\circ} 52.194^{\prime} \mathrm{S} ; 40^{\circ} 50.713^{\prime} \mathrm{W}$, in a water depth of 1846 meters (Fig. 1). Sponge spicules from middle Eocene siliceous nannofossil oozes (thickness, $58 \mathrm{~m}$ ) were examined. These sediments were disconformably overlain by middle Miocene diatomaceous and siliceous nannofossil ooze.

Hexactinal sponge spicule assemblages were the primary group encountered in these sediments; tetractinal sponge spicules were subordinate. Among the hexactinal spicules, hexactines and pentactines with ray widths of $30 \mu \mathrm{m}$ and broken ends were often present. Oxyhexactines (DV 3 ) were very numerous. Hexactines with rough surfaces, extra crossbeams, and rudimentary axial rays were found. Pentactines were very fine and thin, with branch widths of $15 \mu \mathrm{m}$, or more massive, with branch widths of $45-60 \mu \mathrm{m}$. Stauractines and anapentactines are represented by very rare specimens. Characteristic spicule forms not found in sediments at Sites 511 and 513 were the curved-branch pentactines.

The middle Eocene sediments may be divided into two sections on the basis of sponge spicule distribution (Fig. 3).

In the lower part (from Sample 512-19,CC to Sample $512-12, \mathrm{CC})$ almost all varieties of monaxons are found: bow-shaped oxeas (DV 5), straight oxeas (DV 4, DV 5), crooked oxeas (DV 1, DV 3), bow-shaped strongyles (DV 1), strongyles transitional to styles (DV 2), straight styles (DV 1), bow-shaped styles (DV 4), and crooked styles. Acanthosubtylostyles constitute an exception; they were seldom found in the middle to upper Eocene ooze above but were present in Sample 512-7-3, 90-92 cm. In- stead, tetraxons such as orthodichotriaenes (DV 1, DV 4) and plagiodichotriaenes (DV 1, DV 3) were found there. Only one tetraxon variety-orthodichotriaenes (DV 3) - was found in younger sediments. Triaxons were found only in the lower part of the middle Eocene and were represented by oxyhexactines (DV 1) and pentactines (DV 1, DV 5).

In the upper part of the middle Eocene there were numerous oxyhexactines (DV 3), hexactines (DV 1), and pentactines (DV 2). The main characteristic of the sponge spicule assemblage in these upper units is the disappearance of some spicules, primarily the monaxons and the majority of the tetraxons and triaxons noted earlier.

Evidently, at the beginning of the middle Eocene water depths were favorable for producing not only hexactinal but also tetraradiate sponges which adapted to unfavorable life conditions. After the death of the sponge organisms, their spicules were transported only short distances. This favored preservation of the fine microscleres.

\section{Site 513}

Site 513 is located on the western flank of the Mid-Atlantic Ridge to the east of the Argentine Basin, at $47^{\circ}$ $34.99^{\prime} \mathrm{S} ; 24^{\circ} 38.40^{\prime} \mathrm{W}$, in a water depth of 4373 meters (Fig. 1).

Lower Oligocene units (96 m thick) were encountered; they consisted of nannofossil ooze with chert at the base that was replaced, upward in the section, by upper Oligocene nannofossil ooze and diatomaceous nannofossil ooze, 85.5 meters thick. Above that were lower Miocene muddy diatomaceous nannofossil ooze and muddy diatomaceous ooze, 28.5 meters thick. The upper part of the section was composed of upper Miocene muddy diatomaceous ooze, 57 meters thick.

In the lower Oligocene assemblages spicules occurred as triaxons, common tetraxons, and rare monaxons. In this section the most characteristic varieties were anaorthodichotriaenes (DV 7b) and proanatriaenes (DV 1) (Fig. 4). Among spicules of nondefined taxonomic position were characteristic varieties with hook-shaped rays, hooked prominent rays, rostriform, rough, prominent rays, and others.

In the upper Oligocene sediments, the sponge spicule composition does not change greatly. The same spicule varieties were present as triaxons, tetraxons, and monaxons, but their distribution and ratio were somewhat different. A peculiarity in the vertical distribution of sponge spicules makes it possible to distinguish lower and upper sections within the upper Oligocene. A relatively large quantity of styles, subtylostyles, and different tetractines characterizes the lower part. Pentactines (DV 2) were found here only. Despite this noticeable distinction between spicule assemblages, it is difficult to draw the boundary precisely. Styles and subtylostyles vanish above Sample 513A-19,CC. Proanatriaenes and orthoanatriaenes did not occur above Sample 513A-17$4,80-82 \mathrm{~cm}$. The only subtylostyles (DV 2) were found in the same sample. Pentactines were not found higher than Sample 513A-17-1, 80-82 cm.

The upper Oligocene is characterized by a large decrease in the quantity and diversity of sponge spicules 


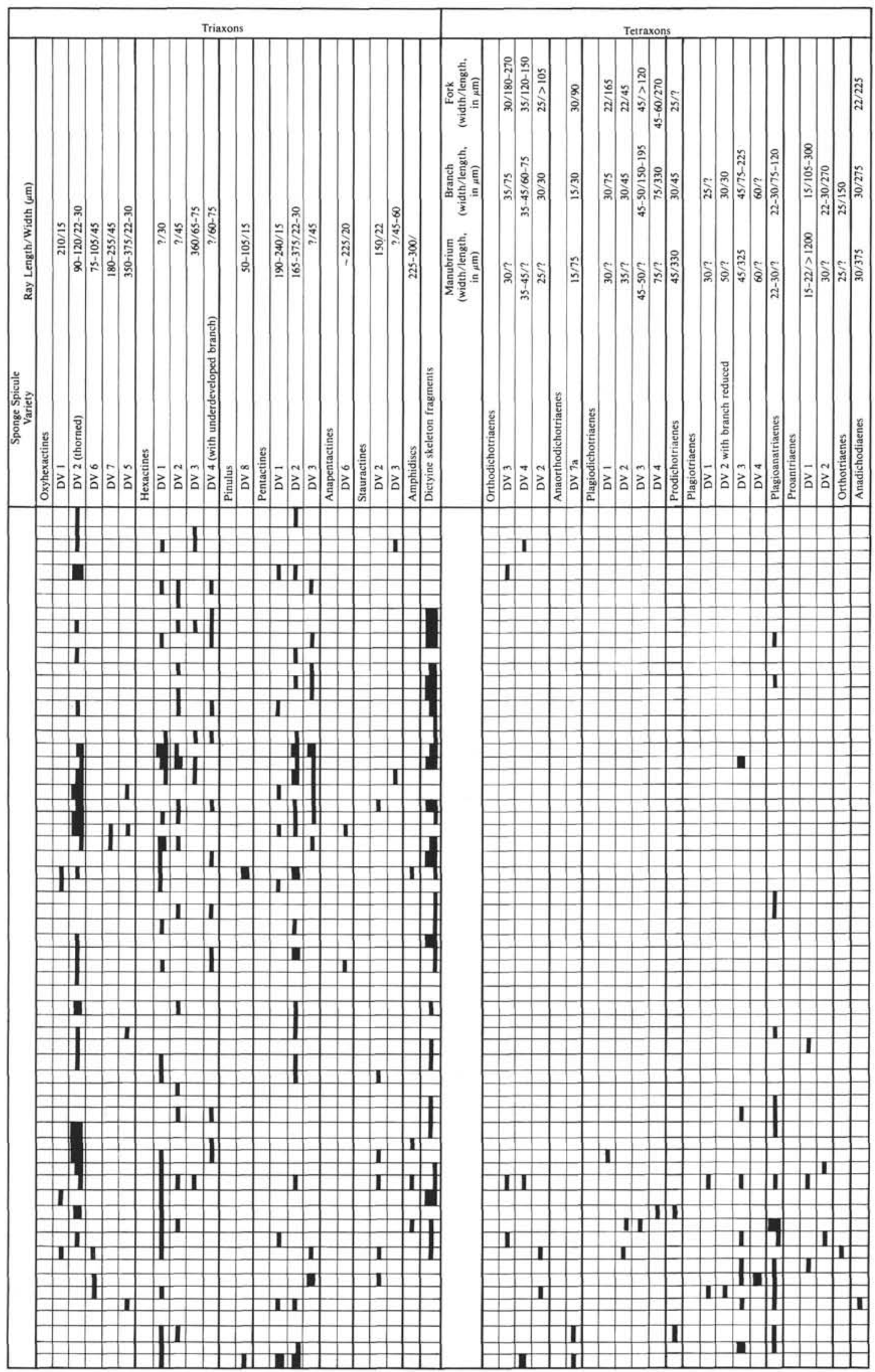

Figure 2. Distribution of upper Eocene-lower Oligocene sponge spicules from Hole 511. 


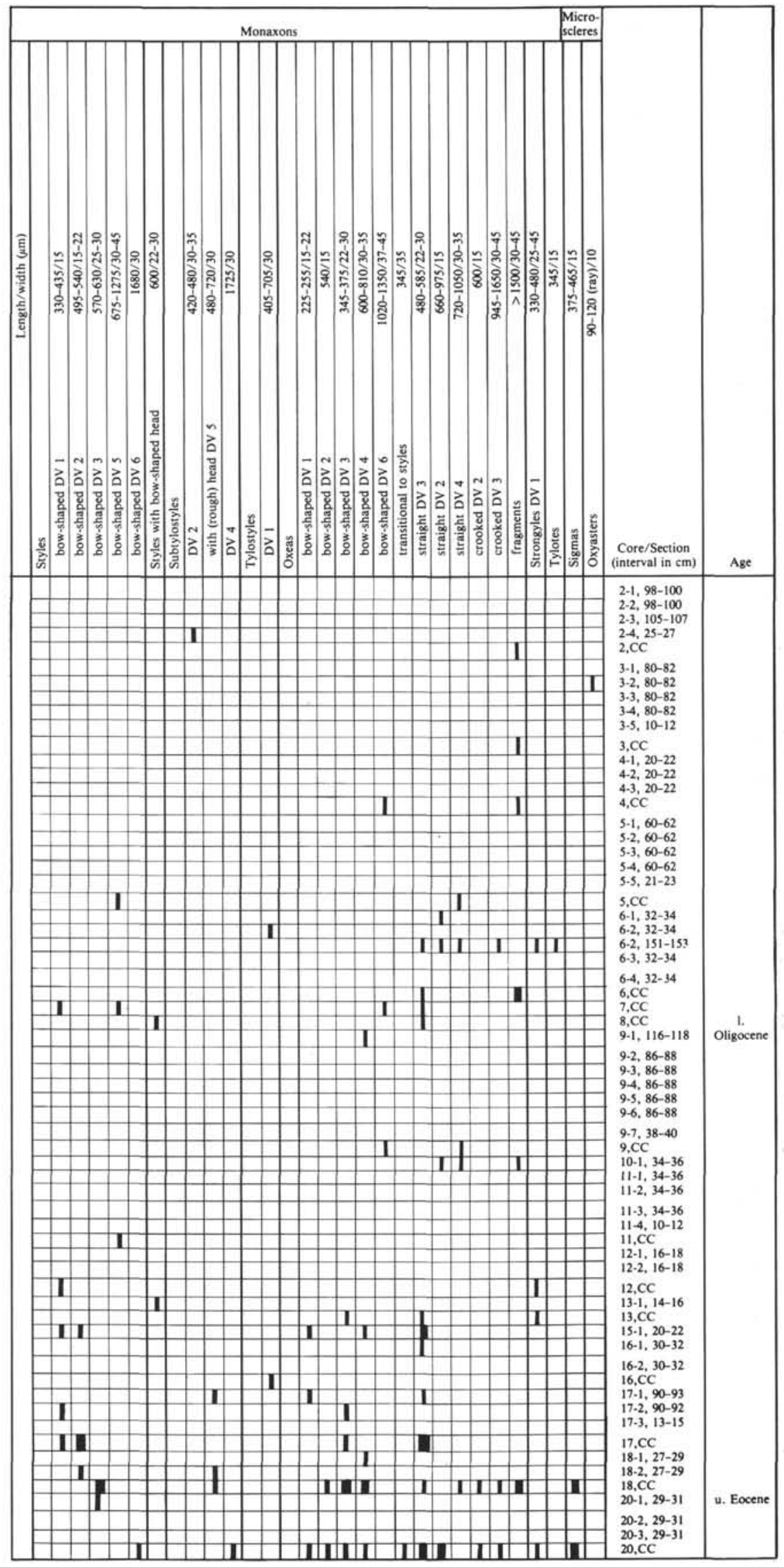

Figure 2. (Continued). 


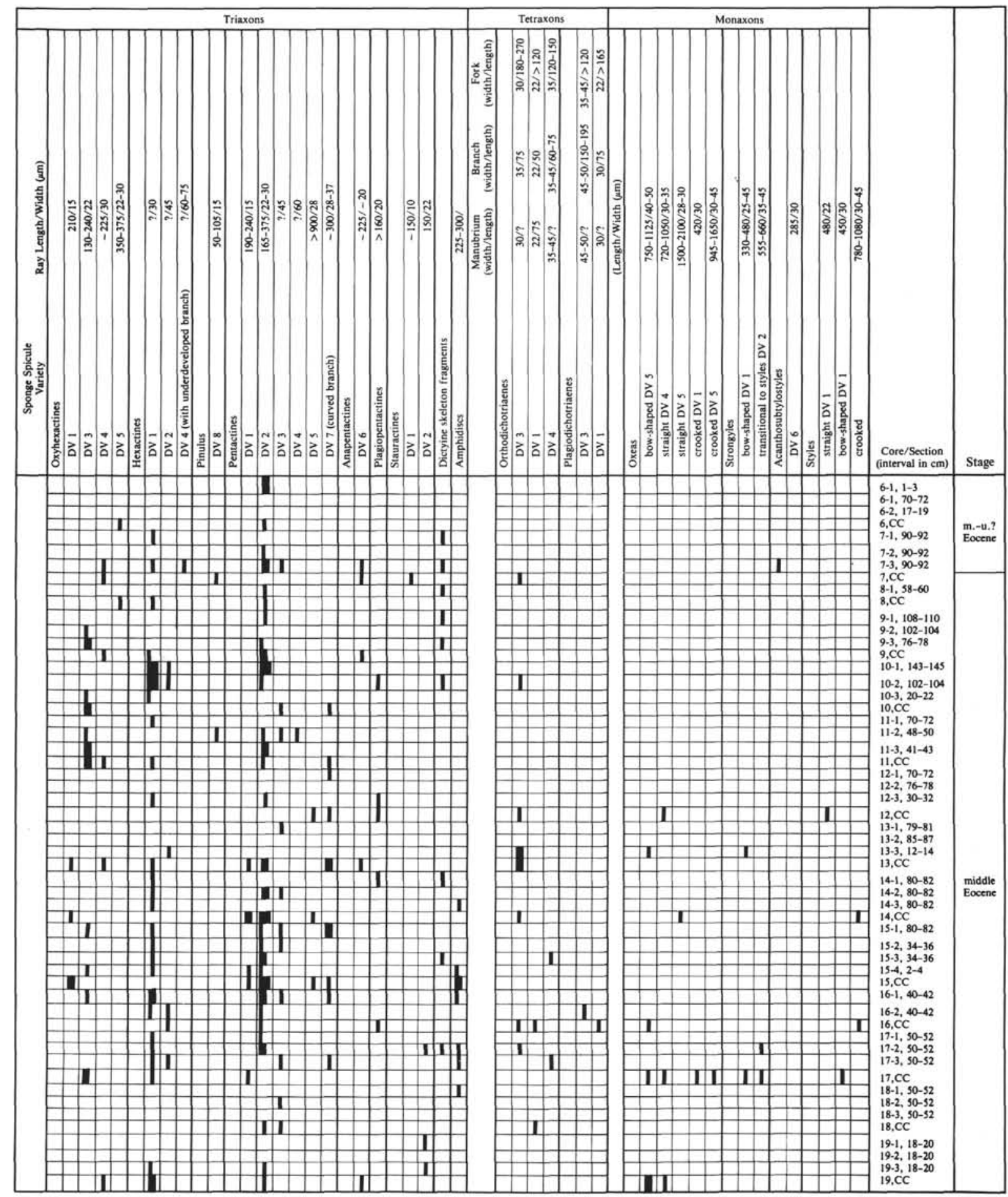

Figure 3. Distribution of middle Eocene sponge spicules from Hole 512A.

compared to the lower part of the section. Rays whose taxonomic position cannot be defined are very common. Some are typical of the lower part: prominent, straight, thick rays (from Sample 513A-24,CC to Sample 513A-16-7, 10-12 cm) and prominent, straight, spiny rays (from Sample 513A-21-6, 67-69 cm to Sample 513A16-7, 10-12 cm). Forms characteristic of the upper part are prominent hooked rays (from Sample 513A-16-6, $10-12 \mathrm{~cm}$ to Sample 513A-15-1, 24-26 cm) and promi- nent, pinule-shaped, large-spined rays (from Sample 513A-16-6, 10-12 cm to Sample 513A-15-1, 24-26 cm).

In middle Miocene sediments, hexactinal sponge spicules occurred only rarely, tetraradiate sponge spicules more often; monaxons were not found at all. This impoverished spicule assemblage consists of hexactines (DV 1), orthodichotriaenes (DV 4, DV 5), and plagiotriaenes (DV 5). The most characteristic rays of nondefined systemic position were prominent, straight, flattened 


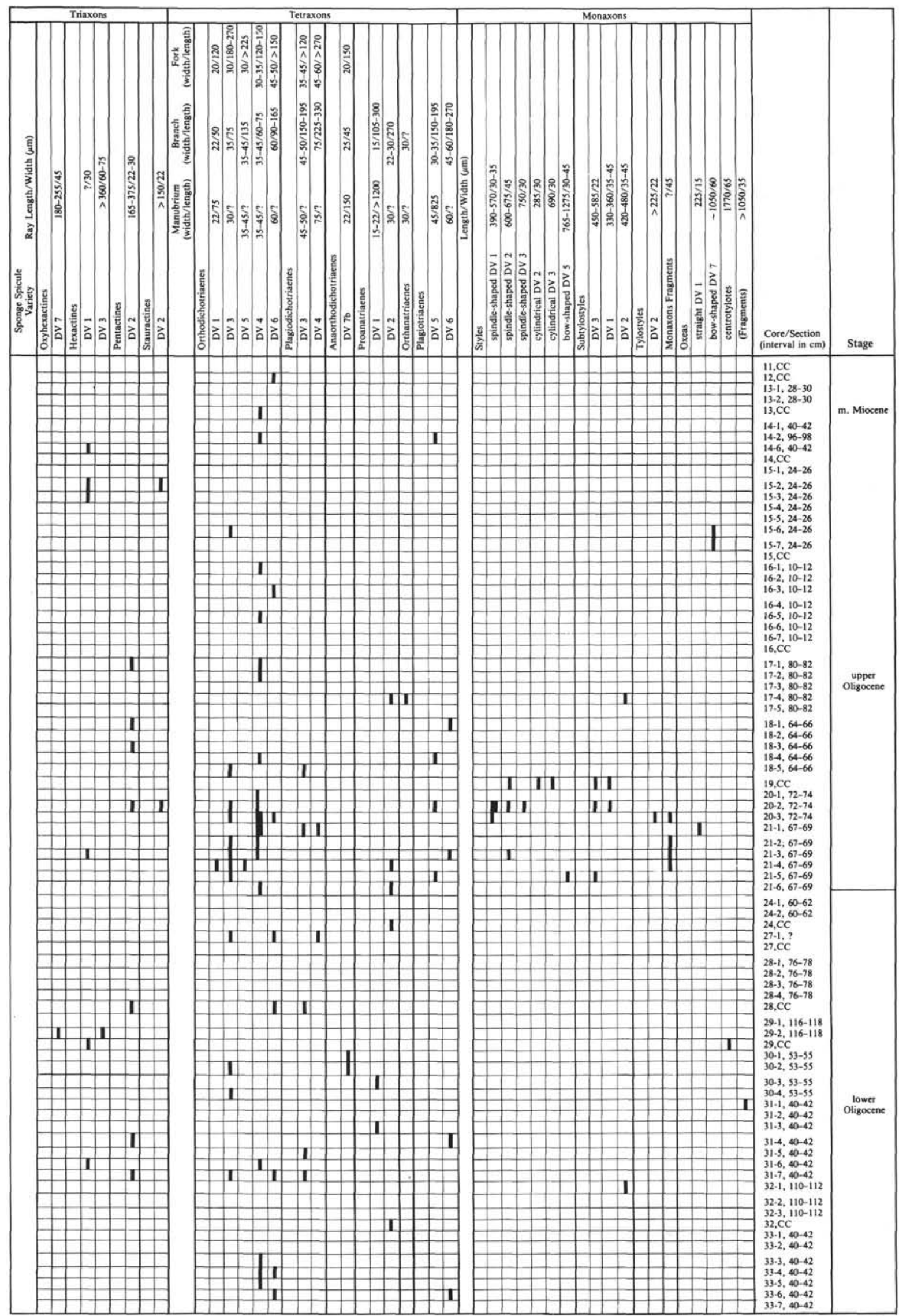

Figure 4. Distribution of lower Oligocene-middle Miocene sponge spicules from Hole 513A. 
rays and prominent straight rays with flattened projections (appendices). In addition a ray group of nondefined systematic position was found in the upper and lower Oligocene sediments, but not in the higher middle Miocene oozes.

In Sample 513A-11,CC (upper Miocene), no sponge spicules were found. Among rays of nondefined types were prominent dichotomous ones.

Judging from the composition of the spicule assemblages the Oligocene and Miocene basin in the area of Site 513 was very deep-evidently no different from recent depths-so that sponges were not widely distributed. The late Oligocene sediments are marked by a dramatic increase in tetraxon spicules which is probably due to spicule displacement.

\section{GENERAL FEATURES OF SPONGE SPICULE DISTRIBUTION}

Sponge spicule distribution at Leg 71 sites reveals definite, regular patterns. Each stratigraphic unit has a characteristic spicule assemblage; thus it is possible to differentiate deposits of different ages (Fig. 5).

The remains of organisms are not always sufficient to classify them on the lowest taxonomic level (species), and it would be premature to discuss the evolutionary development of the organisms. In addition, more or less similar spicule types and varieties are observed at different levels of the Cenozoic sections. The stratification differences do not exclude a relationship to the same species, and thus the appearance or disappearance of particular spicules may depend on ecologic factors. Being benthic and sedentary organisms, sponges are strongly subject to ecologic effects, and as a rule ecologic changes are reflected in their composition. Because the Leg 71 material is rather limited, it is difficult to distinguish between local ecologic and evolutionary changes.

Data from Leg 71 make it possible to correlate spicule assemblages from the lower Oligocene oozes at Sites 511 and 513. Spicules restricted to the lower Oligocene sediments of both sites are oxyhexactines (DV 7), hexac-

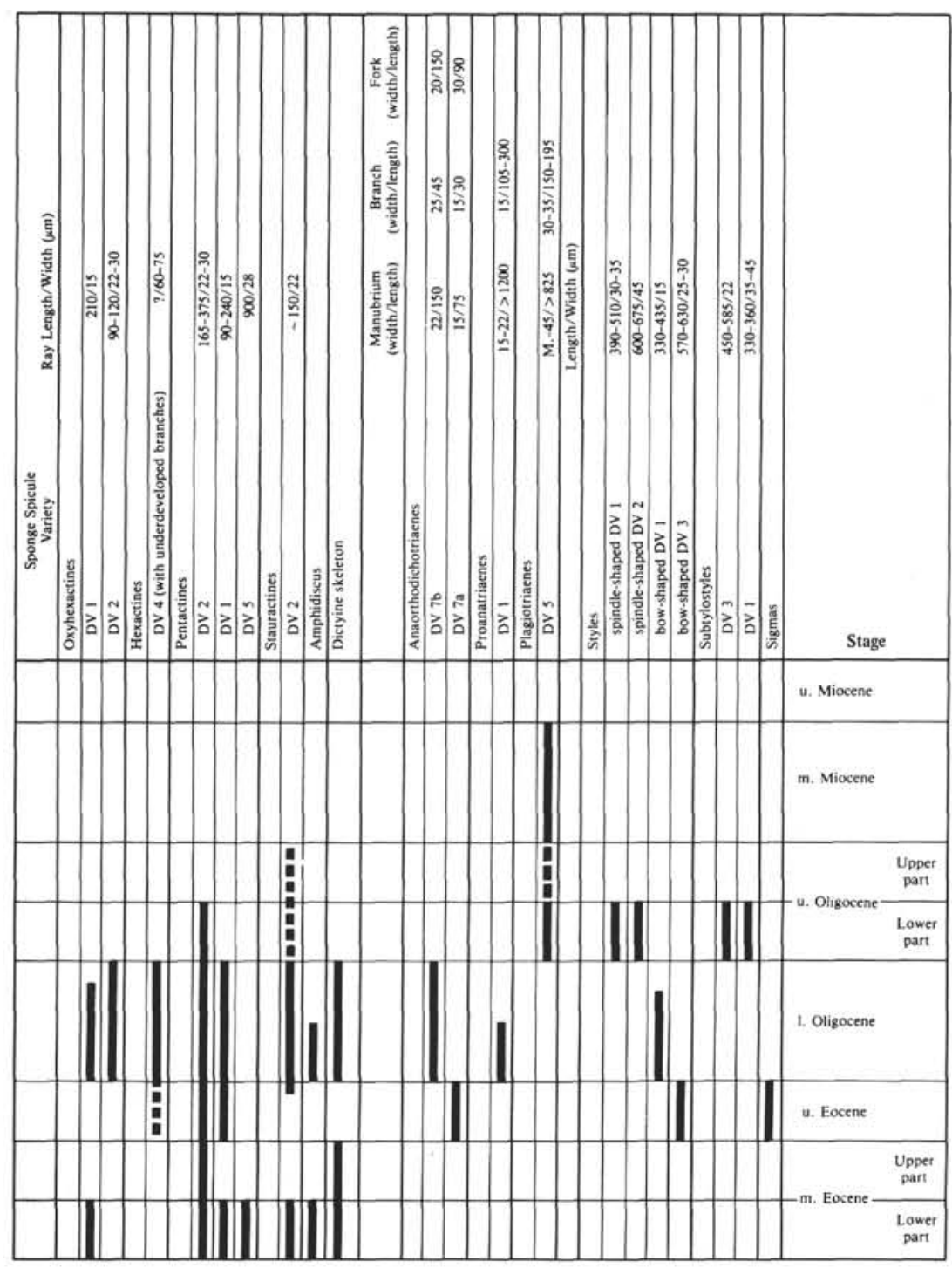

Figure 5. Distribution of middle Eocene-upper Miocene sponge spicules at Sites 511, 512, and 513 . 
tines (DV 3), and proanatriaenes (DV 1). Common also are hexactines (DV 1), pentactines (DV 2), orthodichotriaenes (DV 3, DV 4), plagiodichotriaenes (DV 3, DV 4), proanatriaenes (DV 2), and subtylostyles (DV 2). These last six types, however, persist in upper Oligocene sediments.

Among spicules of nondefined taxonomic position, some types are characteristic of the lower Oligocene of Sites 511 and 513, including prominent, hooked, rough rays, hooked middle-curved rays, serpentine hooked rays, and prominent thick rays.

These data testify that in spite of the distance between Sites 511 and 513 and their position in different geomorphological areas, sponge assemblages can be used to correlate sediments quite well.

\section{ECOLOGIC INTERPRETATION}

Hexactinal sponges, the spicules of which dominate assemblages from the Leg 71 sites, are seldom found at depths of less than 100 meters, register their maximum development at 500-1000 meters, and exist at depths of up to 5000 meters. Hexactinal sponges are typical ocean organisms-they live only in seas directly connected with open oceans. They are sedentary and benthic, intense biofiltrators, and prefer massive substratum. Silty bottoms may clog pores (channels) and destroy the sponges, although many representatives of the hexactinids - the family Hyalonematidae (amphidiscs with unjointed skeletons) and the family Caulophacidae (without dictyine skeletons, always diactine, and others) are adapted to life on silty bottoms and other similar substrates by a long leg, that consists of a bunch of spicules.

Preservation of the sponge remains and changes in spicule composition make it possible to define the living conditions of these organisms as well as some features of sedimentation near Sites 511, 512, and 513 .

Assemblages in upper Eocene sediments at Site 511 are dominated by the spicules of tetraradiate sponges, which live at shallower depths and thus at higher water temperatures than hexactinal sponges (their maximum development occurs at depths of 100-400 m, compared to the $500-1000 \mathrm{~m}$ of hexactinal sponges).

During the late Eocene at Site 511, the average water temperature for the region was probably higher than in the early Oligocene, or ocean depth was less. In addition, active bottom currents resulted in transport of sponge skeletons some distance after death, for primarily massive spicules are present in the assemblages. At the same time, transport was not sufficient to destroy such finely constructed microscleres as amphidiscs, which are very seldom preserved as fossils.

Although Oligocene sediments at Sites 511 and 513 are well correlated by means of spicules, the life conditions of sponges in these regions were different. In particular, the absence of amphidiscs in the Site 513 section indicates a more active hydrologic regime.

The rather scanty occurrence of sponge remains in the Miocene implies that life and burial conditions were unfavorable for sponges.
During middle Eocene time in the region of Site 512, life conditions for sponges were similar to those around Site 511. Ocean depths were favorable for hexactinal sponge development, less favorable for tetraradiate sponges. Spicules of the prominent-ray type disappeared almost completely.

The upper Eocene sediments of Site 511 and the middle Eocene oozes of Site 512 contain amphidiscs. Their presence indicates favorable burial conditions and minimal after-death spicule transport.

\section{SPONGE SPICULE CLASSIFICATION AND DESCRIPTION}

The fossil skeleton remnants of joined and discrete sponge spicules are related to a variety of taxonomic units but it is difficult to determine their taxonomic affinities from the disarticulated skeletons found at Leg 71 sites. First, there is still no uniform classification of the poriferans even at the level of large taxonomic units such as classes and orders. In developing a classification some scientists give priority to sponge microscleres and to a certain extent to macroscleres; others consider a variety of different morphological features, which cannot be found in fossil sponges. Consequently, paleontologists cannot use all the taxonomic principles of zoology that are used to classify recent sponges. After death a sponge decomposes, and the isolated spicules disperse on the bottom of the basin; sponge skeletons joined in life are often broken by the action of bottom and turbidity currents. The difficulty of identification is compounded when extinct sponge groups are at issue.

In spite of these facts, sponge spicule analysis does allow a more or less exact determination of the taxonomic position of sponges found in the Cenozoic sediments of Sites 511, 512, and 513. In the Paleogene of the South Atlantic, sponges of the class Hyalospongiae were widespread, representatives of the class Demospongiae less common. According to modern classifications, the class Hyalospongiae is subdivided into the orders Amphidiscophora and Hexasterophora (Bakus, 1977). The microscleres of the former are represented by amphidiscs, the latter by hexasters. Some investigators follow Zittel's $(1877,1879)$ classification, because microscleres are only very rarely preserved in a fossil state and cannot be related to a definite systematic subdivision. Zittel subdivided all hexactinal sponges into two groups: Lyssacina includes all sponges with amphidiscs and hexactinal sponges with unjoined skeletons, Dictyonina all hexactinal sponges with spicules joined in a unit lattice.

Amphidiscs in middle Eocene sediments of Site 512 and lower Oligocene oozes of Site 511 indicate the presence of the order Amphidiscophora (Lyssacina). Sponges with joined skeletons (Dictyonina) are prominent in the assemblages from the lower Oligocene of Site 511. In the material from the class Demospongiae were representatives of the orders Tetraxonida and (probably) Cornacuspongida. Characteristic macroscleres such as dichotriaenes, protriaenes, plagiotriaenes, and anatriaenes point to the presence of sponges of the order Tetraxonida. Also found were monaxial monactines and di- 
actines which are present in different sponge species. Sigmas from the upper Eocene sediments of Site 511 are found in many species of the order Cornacuspongida and in the suborder Sigmatophora of the Tetraxonida.

\section{CLASS HYALOSPONGIAE}

\section{Group DICTYONINA}

Dictyonina include sponges with a dictyional skeleton formed of joined hexactines. Many families in this group have irregular dictyional skeletons thickened in the dermal layer with thickened rays. Relatively large fragments of such skeletons were found in lower Oligocene sediments at Site 511 . Maintaining a common hexagonal form by means of extra crossbeams, they often display cells of irregular tetragonal or three-cornered form, a pattern vividly seen in Plate 2, Figure 1.

In the material studied, thickened and apparently protruding rays with one end solid and the other branched are particularly prevalent in sponge spicule assemblages from Oligocene and Miocene sediments. Similar rays are shown for Holascella taraxacum in Lendenfeld (1915, table 22). Lendenfeld, however, did not classify them, but named them "the outer protruding ray of superfacial (hypodermal, hypogastral) hexactines." In our varieties, unlike those of Lendenfeld, there is no accurate hexagonal construction. Instead, branches are formed at the ray base, not at right angles as in regular hexactines, but at an acute angle downward. Similar branches from the main ray are usually seen at a $45^{\circ}$ angle in lychniscs, arranged more regularly.

Morphologically considered, these thickened, protruding rays appeared diverse; they also have a restricted geologic range. Owing to their taxonomic uncertainty (no rays were found with well-preserved branches), no attempt was made to describe them. As noted earlier, it is possible to consider them radiolarians.

\section{Group LYSSACINA}

\section{Macroscleres}

Oxyhexactines (Plate 1, Figs. 1-4). Spicules represent hexactines with pointed ray ends like oxeas. On the basis of their morphological characteristics and dimensions, dimensional varieties (DV) are: DV 1: 210,$15 ;{ }^{2}$ middle Eocene at Site 512 and lower Oligocene at Site 511. DV 2: (branch) 90-120, 22-30, with spinules and clearly visible axial channels; numerous only in the lower Oligocene at Site 511. DV 3: 130-240, 22; characteristic of the middle Eocene at Site 512. DV 4: about 225, 30; distributed as DV 3. DV 5: 350-375, 22-30; upper part of the middle Eocene at Site 512 and the upper Eocene-lower Oligocene at Site 511. DV 6. 75-105, 45; upper Eocene and the lower part of the lower Oligocene at Site 511. DV 7: 180-255, 45; lower Oligocene at Sites 511 and 513.

Pentactines (Plate 2, Figs. 2, 5; Plate 3, Figs. 1, 5). Triaxons with five rays, four of which are usually arranged in one plane. Dimensional varieties are: DV 1: 190-240, 15; middle Eocene of Site 512, upper Eocene and lower Oligocene of Site 511. DV 2: 165-375, 22-30; the most widely distributed sponge spicule, occurring in great quantity in the middle Eocene at Site 512, often in the upper Eocene and lower Oligocene at Site 511, and present in the Oligocene at Site 513. DV 3: indeterminable, 45; common, but not in great quantity in the middle Eocene at Site 512, also in the upper Eocene and Oligocene at Site 511. DV 4: indeterminable, 60; seldom in the middle Eocene at Site 512. DV 5: >900, 28; distributed as DV 4. DV 6 (anapentactines-pentactines where branch endings are recurved downward as in anatriaenes; see Plate 2, Fig. 2): 225, 20; middle Eocene of Site 512 and lower Oligocene of Site 511. DV 7 (plagiopentactines-pentactines with curved branches; Plate 3, Fig. 5): about 160-300, 20-37; characteristic of middle Eocene sediments. DV 8 (pinulus): pentactine or hexactine varieties of which the long ray possesses curved spinules facing the free ray ending (Plate 3, Figs. 3-4); both varieties occur infrequently in the middle Eocene of Site 512 and the upper Eocene-lower Oligocene at Site 511 .

Hexactines (Plate 1, Figs. 5-8; Plate 2, Figs. 3-4). Triaxons with six rays, when joined, sometimes form dictyional skeletons of hex-

\footnotetext{
${ }^{2}$ The first figure following the DV number refers to the ray length in $\mu \mathrm{m}$, the second to the width in $\mu \mathrm{m}$.
}

actinal sponges. There are four dimensional varieties, distinguished here by ray width: DV $1: 30$, often in great quantity in the middle Eocene of Site 512 and in the upper Eocene and lower Oligocene of Site 511; seldom found in the lower and upper Oligocene and middle Miocene of Site 513. DV 2: 45; middle Eocene at Site 512; more common in the upper Eocene and lower Oligocene at Site 511. DV 3: $60-75$, length $>360$; common in the lower Oligocene at Site 511 and in the lower Oligocene at Site 513. DV 4: two underdeveloped rays along one of the axes; width of main rays $60-75$, common in the lower Oligocene of Site 511; one specimen found in the middle Eocene at Site 512.

Stauractines (Plate 2, Fig. 6; Plate 3, Fig. 2). Stauractines result from the reduction of two rays along one of the axes of hexactines; they are tetractines of which the four rays lie in one plane at $90^{\circ}$ angles to each other. Dimensional varieties are: DV 1: (branch) 150, 10; seldom seen in the middle Eocene at Site 512. DV 2: (branch) 150, 22; lower part of the middle Eocene at Site 512, upper Eocenelower Oligocene at Site 511, and upper Oligocene at Site 513. DV 3: (branch) indeterminable, width 45-60; rare in the lower Oligocene sediments of Site 511 .

\section{Microscleres}

Amphidiscs (Plate 3, Figs. 6-7). Anchorlike microscleres of hexactinal sponges, including a rod with numerous branches on both ends. Branch ends are bent backwards, and sometimes branches are joined, forming a shape like an indented umbrella. In this study three kinds of amphidiscs were distinguished: (1) giant; (2) oval; (3) umbrella-shaped. Found in the middle Eocene of Site 512 and the lower Oligocene of Site 511.

\section{Class DEMOSPONGIAE}

\section{Order TETRAXONIDA}

Tetraxons (Figure 6)

Orthodichotriaenes (Plate 4, Figs. 1-3). Dichotriaenes with branches and forks at right angles to the manubrium. Dimensional varieties are: DV 1: shortened manubrium 22, 75; branch 50, 22; fork $>120,20 .^{3}$ The latter usually occur in dermal layers of four-rayed sponges; middle Eocene sediments of Site 512. Separate specimens have been found at the base of the upper Oligocene at Site 513. DV 2: manubrium 25 (width; the manubrium ending in all specimens was broken); very short branch 30,30 ; fork >105, 25 (at base); transitional layers between the lower Oligocene and upper Eocene at Site 511. DV 3: manubrium 30 (width); branch 35 (flattened), 75; very long forks, 30-180-270; widespread in the middle Eocene at Site 512, in the lower Oligocene at Site 511, and the lower and upper Oligocene sediments at Site 513. DV 4: manubrium $35-45$ (width), branch $35-45,60-75$; fork 30-45, 120-150; same distribution as DV 3; rare in the lower Miocene at Site 513. DV 5: manubrium 35-45 (width); branches (135), fork 30, >225; common in the lower layers of the upper Oligocene at Site 513. DV 6: manubrium 60 (width); branch 60,165 ; fork $45-50,>150$; Oligocene and Miocene sediments at Site 513. DV 7 (anaorthodichotriaenes): branches at right angles to the manubrium, but the forks are easily bent to the manubrium as in anatriaenes; manubrium shortened, branches and forks usually flattened. Two forms of DV 7 were isolated. DV 7A: manubrium 15, 75; branch 30,15 ; fork 30,90 . DV 7 b: manubrium 22,150 ; branch 25,45 ; fork 20,150; the first form (DV 7a) occurred in the upper Eocene at Site 511, the second (DV 7b) in the lower Oligocene at Site 513.

Plagiodichotriaenes (Plate 4, Figs. 5-6). Dichotriaenes with branches at a moderate angle outward from the manubrium. Dimensional varieties are: DV 1: manubrium 30 (width); branch 30,75 ; fork 22 , $>165$; rarely found in the lower part of the middle Eocene sediments of Site 512 and in lower Oligocene oozes of Site 511. DV 2: manubrium 35 (width); very short branches 30 ; flattened forks 22 , 45; lower Oligocene at Site 511. DV 3: manubrium 45-50 (width); branch 45-50, 150-195; fork 35-45>120; lower part of the middle Eocene at Site 512, lower Oligocene at Site 511, and lower and upper Oligocene at Site 513. DV 4: massive forms with manubrium

\footnotetext{
${ }^{3}$ Dimensions are given in order width, length, in $\mu \mathrm{m}$.
} 


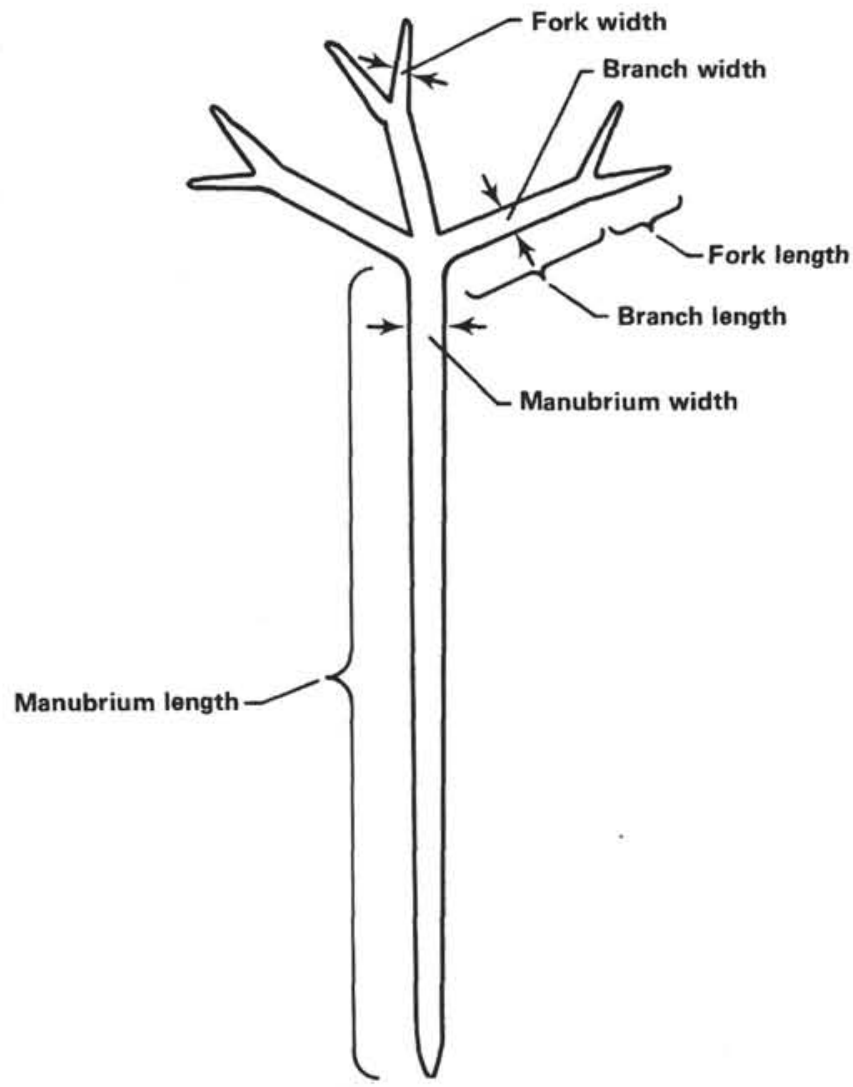

Figure 6. Diagram of tetraxon showing parts and measurement points.

75 (width); branch 75, 255-330; fork 45-60 >270; common in the lower Oligocene at Site 513.

Prodichotriaenes (Plate 4, Fig. 4). Dichotriaenes with branches directed outward from the manubrium. Prodichotriaenes with manubrium 45,330 ; branch 30,45 , and fork 25 (width) were found in the upper Eocene and lowermost Oligocene at Site 511.

Anadichodiaenes (Plate 5, Fig. 2). Anadichotriaenes with one branch completely reduced. Anadichodiaenes with manubrium $30,>375$; branch 30, 285; fork 22, 225 were found in the upper Eocene at Site 511 .

Anatriaenes (Plate 5, Figs. 1, 3). Triaenes with branches bent back toward the manubrium. Two varieties were distinguished. Proanatriaenes are anatriaenes with branches bent at a sharp angle back toward the manubrium (Plate 5, Fig. 1). Plagioanatriaenes are anatriaenes with branches bent at a moderate angle back toward the manubrium (Plate 5, Fig. 3). Dimensional varieties of proanatriaenes are: DV 1: manubrium 15-22, >1200; branch 15, 105300; lowermost Oligocene at Site 511 and the lower Oligocene at Site 513. DV 2: manubrium 30 (width); branch 22-30, 270; lower Oligocene at Site 511 and lower Oligocene to the lower part of the upper Oligocene at Site 513. Plagioanatriaenes are not subdivided into varieties. We found plagioanatriaenes with manubrium $22-30$ (width), branch 22-30,75-120, in the lower Oligocene and upper Eocene at Site 511.

Plagiotriaenes (Plate 4, Fig. 7; Plate 5, Fig. 5). Triaenes with branches directed gently outward from the manubrium. Dimensional varieties are: DV 1: manubrium 30 (width); branch 25 (width); upper Eocene and the lowermost Oligocene at Site 511. DV 2: manubrium 50 (width); reduced branches 30,30; rare in the upper Eocene at Site 511. DV 3: manubrium 45, 325; branch 45, 75-225; upper Eocene and the lower Oligocene at Site 511. DV 4: manubrium 60 (width); branch 60 (width); rare in the upper Eocene of Site 511. DV 5: manubrium 45, >825; branch 30-35, 150-195; upper Oligocene and middle Miocene at Site 513. DV 6: manubrium 60 (width); branch 45-60, 180-270; lower-upper Oligocene at Site 513.
Plagiomesotriaenes (Plate 5, Fig. 4). Plagiotriaenes in which the manubrium appears on both sides of the cladome; rare in the lower Oligocene of Site 511.

\section{Monaxons}

Styles (Plate 6, Figs. 1, 3-4, 6, 9). Monaxons pointed at one end and rounded at the other. In the material under study bow-shaped, straight cylindrical, spindle-shaped, and crooked styles and styles with bow-shaped heads are identified.

Dimensional varieties of bow-shaped styles are: DV 1: 330435,$15 ;{ }^{4}$ lower Oligocene at Site 511 only. DV 2: $495-540$ and width 15-22; characteristic of the upper Eocene and lowermost Oligocene of Site 511. DV 3: 570-630, 25-30; common in the upper Eocene at Site 511. DV 4: 450, 30; rare in the middle Eocene at Site 512. DV 5: 765-1275, 30-45; common in the lower Oligocene of Site 511, rare in the lowermost part of the upper Oligocene at Site 513. DV 6: 1680, 30; rare in the upper Eocene at Site 511.

Dimensional varieties of spindle-shaped styles are: DV 1: 390-510, 30-35; DV 2: 600-675, 45; DV 3: 750, 30.

All varieties were found in the lowermost part of the upper Oligocene at Site 513. Dimensional varieties of straight cylindrical styles are: DV 1: 480, 22; middle Eocene at Site 512. DV 2: 285, 30; rare in the upper Oligocene at Site 513. DV 3: 690, 30; rare in the upper Oligocene at Site 513.

Crooked styles are not subdivided into dimensional varieties; dimensions are $780-1080,30-45$. They were found in the middle Eocene only. Styles with bow-shaped heads have dimensions 600 , 22-30. They occurred in the lower Oligocene at Site 511.

Subtylostyles (Plate 6, Fig. 7). Monaxons pointed at one end and with a wide rounded edge on the other end. Dimensional varieties are: DV 1: $330-360,35-45$; lower part of the upper Oligocene at Site 513. DV 2: 420-480, 30-35; lower part of the upper Oligocene at Site 513 and upper part of the lower Oligocene at Site 511; DV 3: $450-585,22$; distribution as DV 1 . DV 4: 1725,30 ; rare in the upper Eocene at Site 511. DV 5: 480-720, 30, with rough head; upper Eocene and the lowermost Oligocene at Site 511. DV 6 (acanthosubtylostyles): 285,30 , with thorny surface; middle Eocene at Site 512.

Tylostyles (Plate 6, Fig. 5). Monaxons pointed at one end and knobbed at the other. Dimensional varieties are: DV 1:345, 15; rarely found in the lower Oligocene of Site 511. DV 2: >225, 22; rare in the upper Oligocene of Site 513.

Oxeas (Plate 6, Figs. 2, 4). Monaxons pointed at both ends. In the material under study, bow-shaped, straight, and crooked oxeas were identified.

Dimensional varieties of bow-shaped oxeas are: DV 1: 225255, 15-22; upper Eocene and lowermost Oligocene. DV 2: 540, 15; upper Eocene at Site 511. DV 3: 345-375, 22-30; distributed as DV 1. DV 4: 600-810, 30-35; distributed as DV 1. DV 5: 7501125, 40-50; lower part of the middle Eocene at Site 512. DV 6: 1020-1350, 37-45; lower Oligocene at Site 511. DV 7: 1050, 60; upper Oligocene at Site 513.

Dimensional varieties of straight oxeas are: DV 1: 255,15 ; Oligocene at Site 513. DV 2: 660-975, 15; upper Eocene and lower Oligocene at Site 511. DV 3: 480-585, 22-30; distributed as DV 2. DV 4: 720-1050, 30-35; middle Eocene at Site 512 and upper Eocene-lower Oligocene sediments at Site 511. DV 5: 1500-2100, 28-30; rare in the middle Eocene at Site 512.

Dimensional varieties of crooked oxeas are: DV 1: 420, 30; rare in the middle Eocene at Site 512. DV 2: 600, 15; upper Eocene at Site 511. DV 3: 945-1650, 30-45; middle Eocene at Site 512; upper Eocene and lower Oligocene at Site 511.

Centrotylote oxeas (Plate 6, Fig. 2) were rare in lower Oligocene sediments of Site 513.

Strongyles (Plate 6, Figs. 10-11). Monaxons rounded at both ends. Dimensional varieties are: DV 1: bow-shaped, 330-480, 25-45; middle Eocene of Site 512 and upper Eocene-lower Oligocene sediments of Site 511. DV 2: strongyles transitional to styles, 555-600, 35-45; rare in the middle Eocene of Site 512.

\footnotetext{
${ }^{4}$ Dimensions are given in the order length, width, in $\mu \mathrm{m}$.
} 


\section{Microscleres}

Sigmas (Plate 4, Fig. 8). Microscleres curved like the letter "CC." Sigmas $(570-630,25-30)$ were common in the upper Eocene of Site 511.

\section{ACKNOWLEDGMENTS}

I express sincere gratitude to Dr. V. A. Krasheninnikov, Co-Chief Scientist of Leg 71 , for providing the Leg 71 material containing sponge spicules and for editing the article. I also thank Dr. V. M. Koltun (Institute of Zoology of the U.S.S.R. Academy of Sciences, Leningrad) for valuable consultation and advice.

\section{REFERENCES}

Bakus, G. J., 1977. Porifera of the Pacific coast of North America. Allan Hancock Foundation, University of Southern California, pp. 1-7.
Haeckel, E., 1887. Report on the Scientific Results of the Voyage of H.M.S. Challenger during the years 1873-76. Zoology, Vol. 18. Report on the Radiolaria: London (Eyre and Spottiswoode).

Koltun, V. M., 1967. Hyalospongiae or Six-rayed Sponges of the Northern and Far Eastern Seas of the U.S.S.R. Opred. faune S.S.S.R., No. 94, Zool. Inst. Akad. Nauk S.S.S.R. (In Russian)

Lendenfeld, R., von. 1915. Reports on the Scientific Results of the Expedition to the Eastern Tropical Pacific...by the Steamer "Albatross". Vol. 29. The Sponges. 3. Hexactinellida. Memoirs of the Museum of Comparative Zoology at Harvard College, Vol. 42: Cambridge, Mass. (The Museum), plate 22.

Sokolov, B. S. (Ed.), 1962. Handbook of Paleontology. Vol. 2: Porifera, Archaeocyatha, Coelenterata, Vermes: Moscow (Akad. Nauk S.S.S.R.), 17-74. (In Russian)

Zittel, K. A., 1877. Studien über fossile Spongien: Hexactinellidae. Abt. 1-3. Abh. K. bayer. Akad., 13:1-90. 1879. Handbuch der Palaeontologie, 1(2): Munich (R. Oldenbourg), 129-202. 


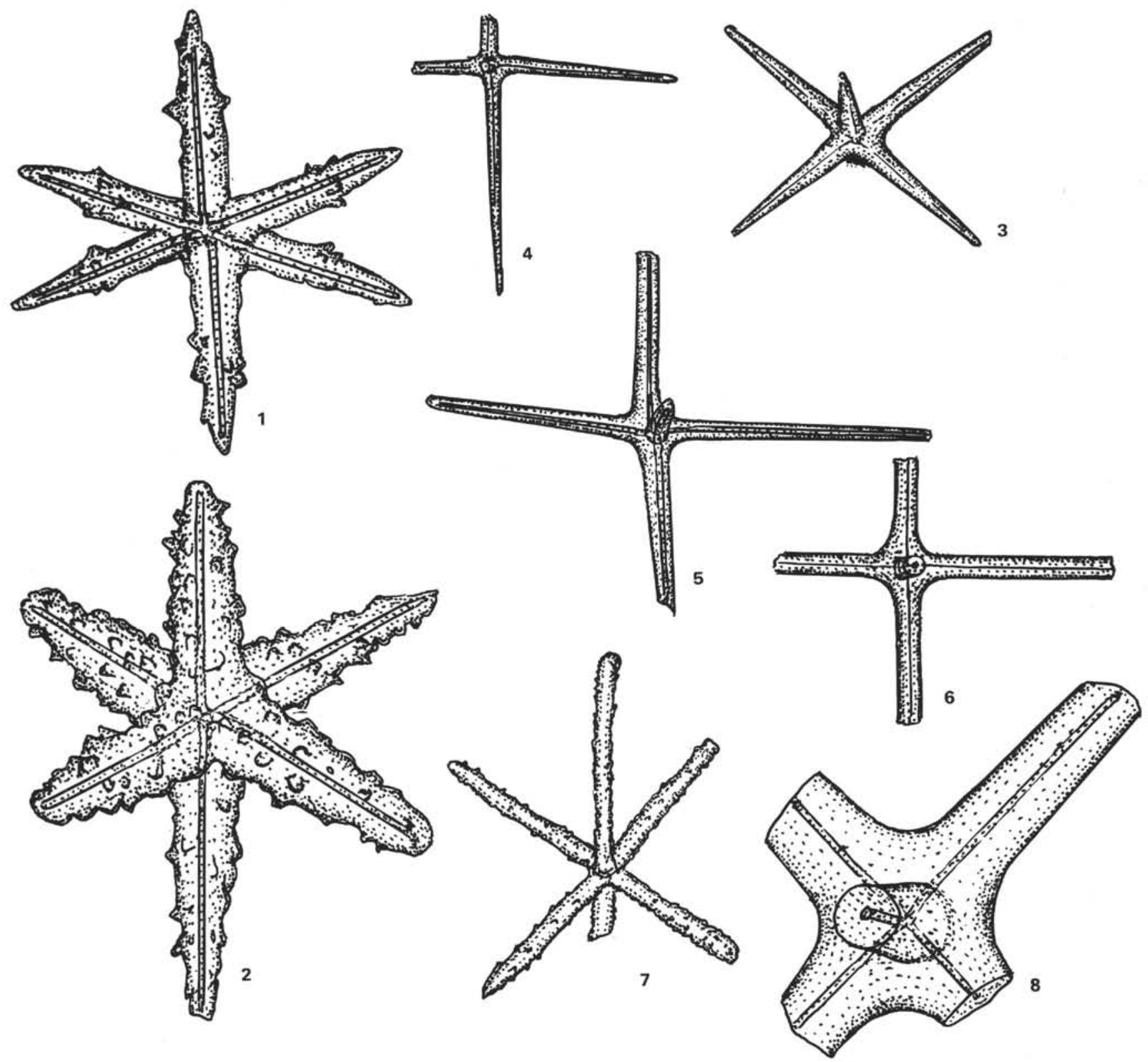

Plate 1. Sponge spicules: triaxons, Hole 511. (All specimens magnified $\times 175$ unless otherwise indicated.) 1-2. Oxyhexactines, thorned (1) Sample 511-13,CC (2) Sample 511-5-4, 60-62 cm. 3-4. Oxyhexactines, $\times 60$. Sample 511-6-2, 151-153 cm. 5-8. Hexactines (5) $\times 60$ Sample 511-6-2, 151-153 cm (6) Sample 511-7,CC. $\times 60$ (7) Sample 511-7,CC (8) Sample 511-5-3, 60-62 cm. 


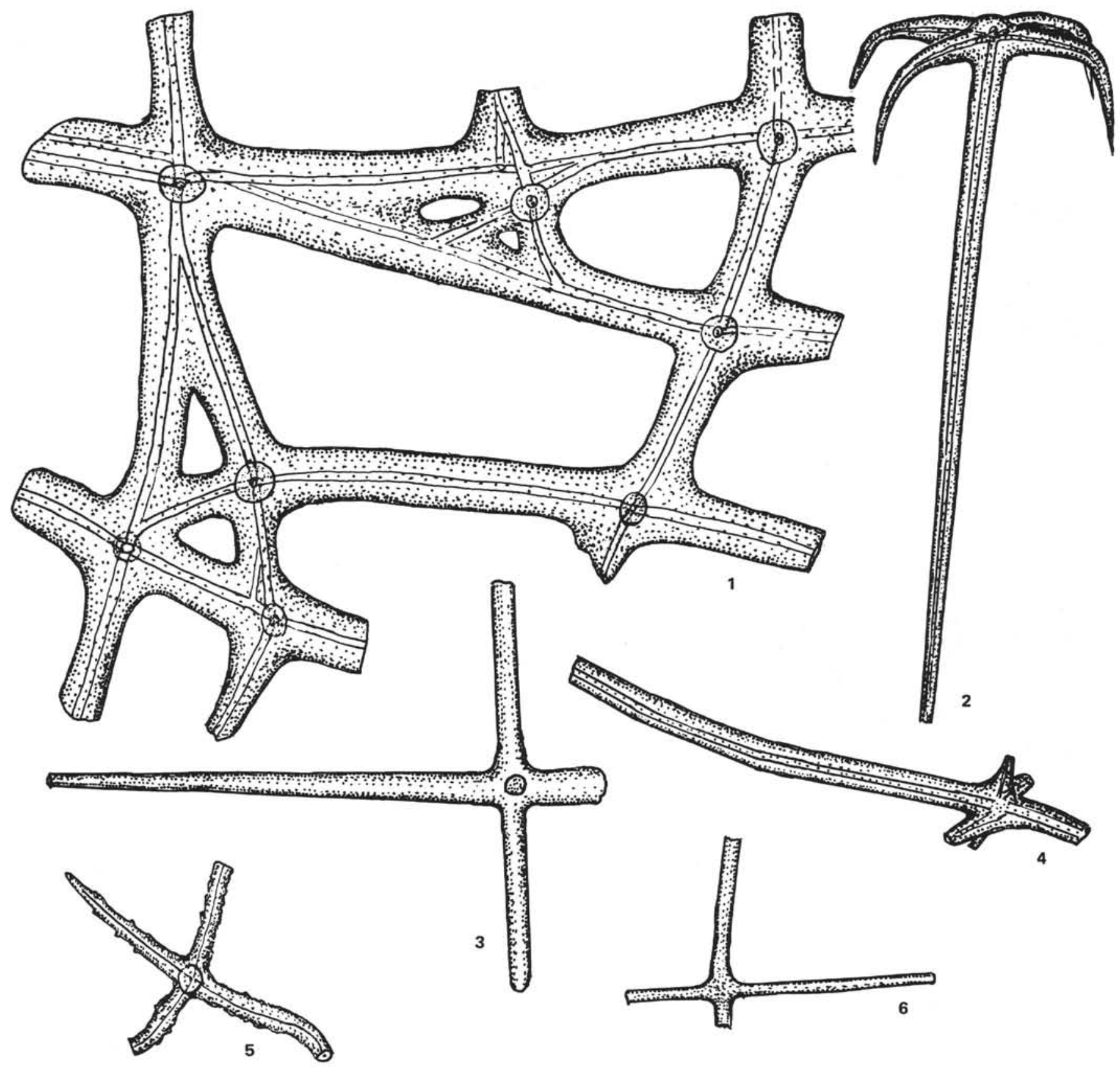

Plate 2. Sponge spicules: triaxons, Holes 511, 512, and 513. (All specimens magnified $\times 60$ unless otherwise indicated.) 1. Dictyine skeleton fragment. Sample 511-5-4, 60-62 cm. 2. Anapentactine. Sample 511-6-2, 32-34 cm. 3. Hexactine, $\times 175$. Sample 511-8,CC. 4. Hexactine with underdeveloped branches. Sample 511-13,CC. 5. Pentactine with curved branches. Sample 512-13,CC. 6. Stauractine. Sample 513A-20-2, $72-74 \mathrm{~cm}$. 


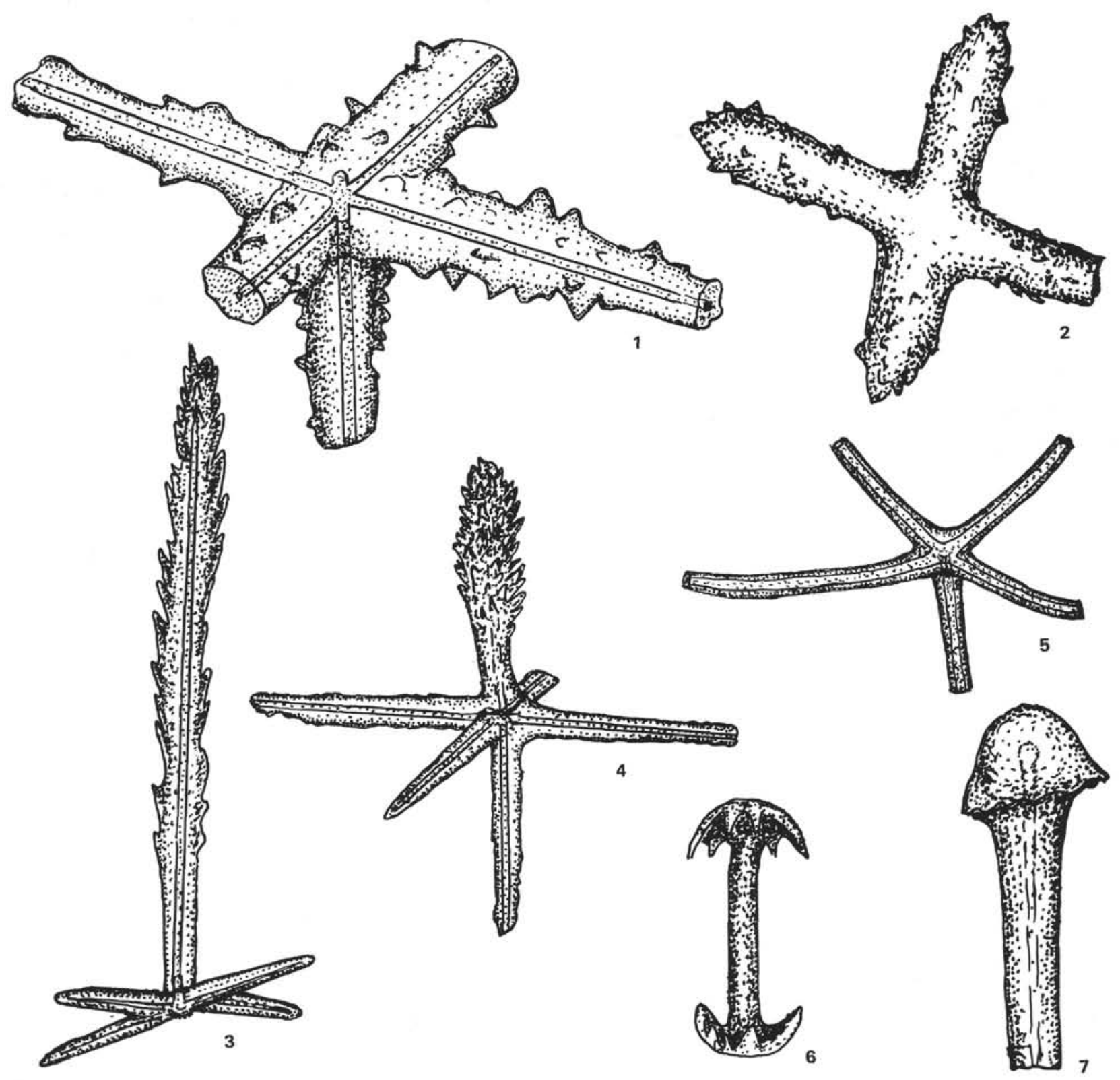

Plate 3. Sponge spicules: triaxons, Holes 511 and 512. (All specimens magnified $\times 175$ unless otherwise indicated.) 1 . Pentactine, knobby. Sample $511-5-3,60-62 \mathrm{~cm}$. 2. Stauractine. Sample $511-16-1,30-32 \mathrm{~cm}, 3-4$. Pinulus. Sample $511-16, C$. 5. Plagiopentactine, $\times 60$. Sample 512-12,CC. 6-7. Amphidiscus (6) $\times 60$. Sample $512-17-2,50-52 \mathrm{~cm}$ (7) Sample $511-15-1,20-22 \mathrm{~cm}$. 

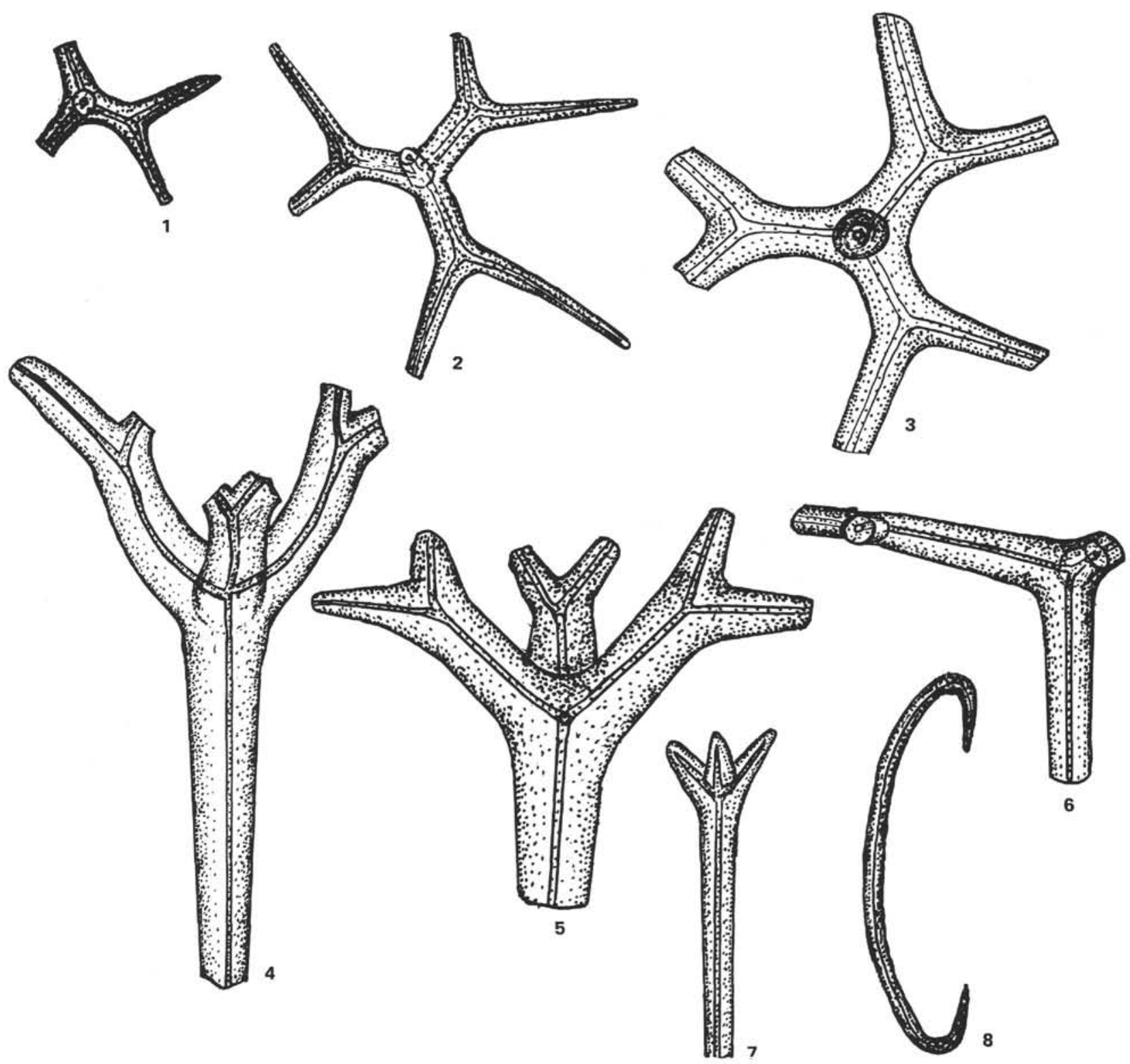

Plate 4. Sponge spicules: tetraxons, Holes 511 and 513A. (All specimens magnified $\times 60$ unless otherwise indicated.) 1-3. Orthodichotriaenes (1) Sample 513A-21-4, 67-69 cm (2) Sample 513A-21-4, 67-69 cm (3) Sample 513A-13-1, 28-30 cm. 4. Prodichotriaene, $\times 175$. Sample 511-20-2, 29-31 cm. 5-6. Plagiodichotriaenes, $\times 175$. Sample 511-17-1, 90-92 cm. (6) Section 513A-27-1. 7. Plagiotriaene with branches reduced. Sample $511-5-4,60-62 \mathrm{~cm}$. 8. Sigma. Sample 511-18,CC. 


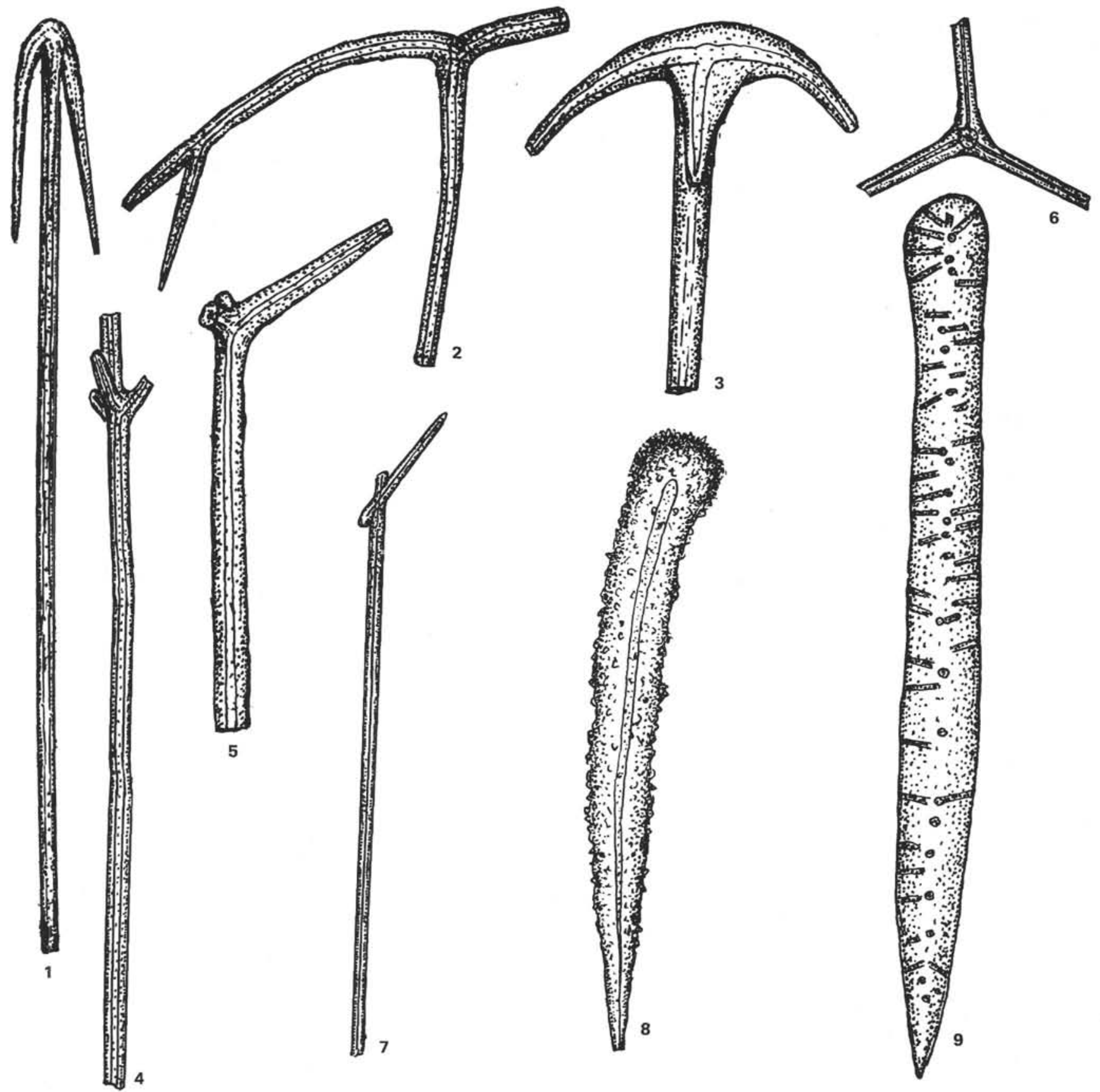

Plate 5. Sponge spicules: triaxons and monaxons, Holes 511, 512, and 513A. (All specimens magnified $\times 60$ unless otherwise indicated.) 1. Proanatriaene, Sample 513A-31-3, 40-42 cm, 2. Anadichodiaene. Sample 511-18,CC. 3. Plagioanatriaene, $\times 175$. Sample 511-17-1, 90-92 $\mathrm{cm}$. 4. Plagiomesotriaene. Sample 511-13,CC. 5. Plagiotriaene. Sample 513A-20-2, 72-74 cm. 6. Orthotriaene. Sample 511-17-3, 13-15 $\mathrm{cm}$. 7. Monaxon accreted with style. Sample 511-9,CC. 8. Acanthosubtylostyle, $\times 175$. Sample 512-7-3, 90-92 cm. 9. Subtylostyle, $\times 175$. Sample 513A-20-2, $72-74 \mathrm{~cm}$. 


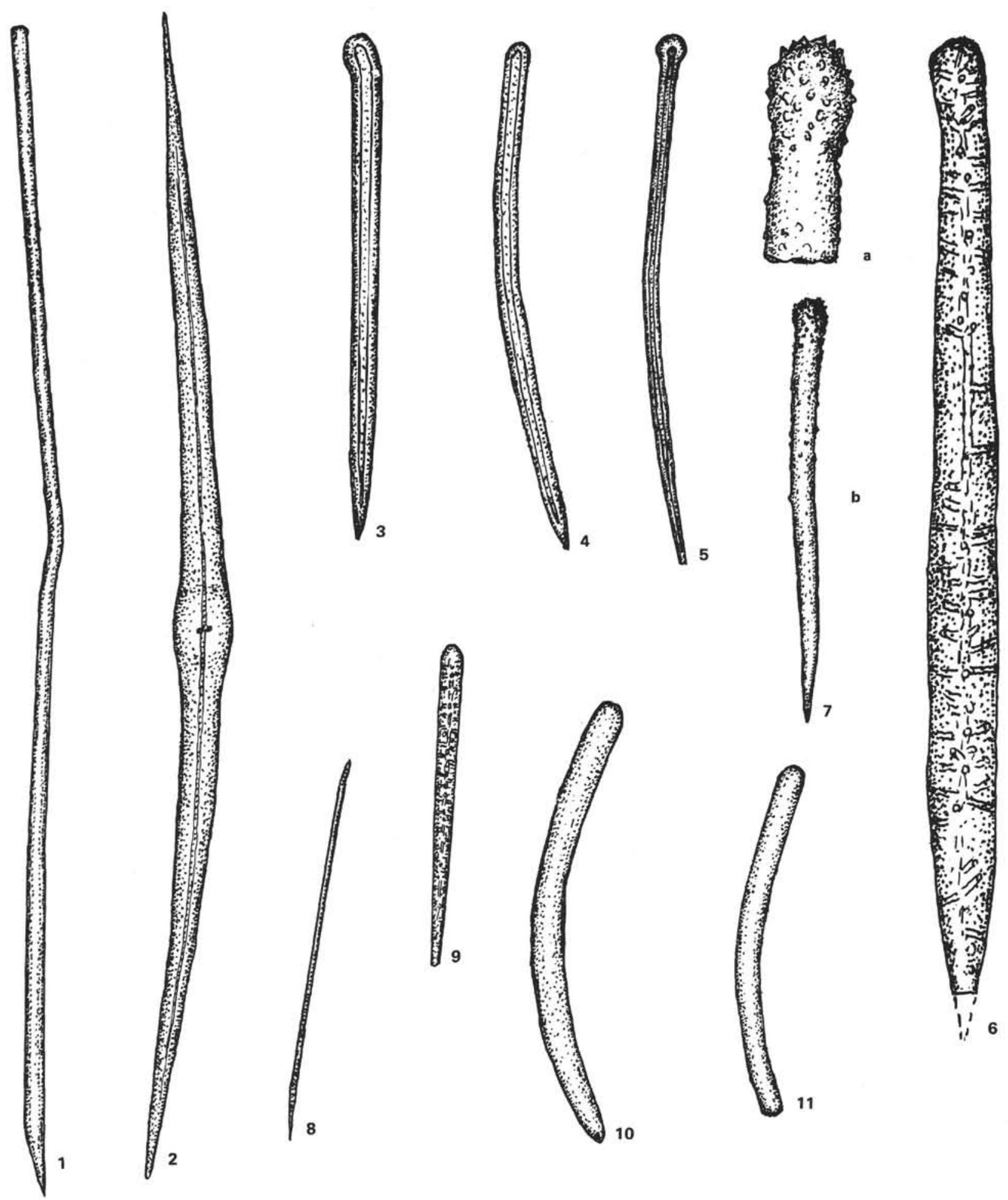

Plate 6. Sponge spicules: monaxons, Holes 511, 512, and 513A. (All specimens magnified $\times 60$ unless otherwise indicated.) 1. Crooked style. Sample 512-14,CC. 2. Oxea (centrotylote). Sample 513A-29,CC. 3. Style with bow-shaped head. Sample 511-13-1, 14-16 cm. 4. Bowshaped style. Sample 511-18,CC. 5. Tylostyle. Sample 511-6-2, 151-153 cm. 6. Spindle-shaped style, $\times 175$. Sample 513A-20-2, 72-74 cm. 7. Subtylostyle with rough head, Sample 511-18,CC (a) head, $\times 175$ (b) side view, $\times 60$. 8. Straight oxea, $\times 175$. Sample 513A-21-1, 67-69 cm. 9. Straight style. Sample 513A-19,CC. 10. Strongyle transitional to style. Sample 512-17-2, 50-52 cm. 11. Strongyle. Sample 511-13,CC. 